\title{
scripted
}

Volume 12, Issue 2, December 2015

\section{COMPUTERS AND THE COALITION: LEGISLATION ON LAW AND INFORMATION TECHNOLOGY, 2010-2015}

\author{
Dr. Daithí Mac Sithigh*
}

DOI: $10.2966 /$ scrip.120215.141

\section{(c) (i) (9)}

(C) Dr. Daithí Mac Síthigh 2015. This work is licensed under a Creative Commons Attribution-NonCommercial-ShareAlike 4.0 International License. Please click on the link to read the terms and conditions.

\footnotetext{
* Dr Daithí Mac Síthigh, Reader in Law, Newcastle University, daithi.macsithigh@ncl.ac.uk
} 


\section{Introduction}

In this contribution, written to mark the 10th anniversary of SCRIPTed and the 2015 launch of the Information Law and Policy Centre at the University of London, I look back on the record of the Coalition government (2010-2015) regarding law and information technology. The written agreement between the Conservative and Liberal Democrat parties ${ }^{1}$ specifically emphasised the importance of technology issues on a number of occasions. Beyond these specific commitments, other issues of significance and controversy emerged during the lifetime of this Government. Although the Coalition is no more, the question of how engaged this administration was with questions of law and technology remains appropriate. In particular, future governments may well grapple with the key tension highlighted in this article; how even parties ostensibly committed to a small and open government may not be able to sustain this outlook or apply it to all legislative and administrative challenges.

The focus of this article is the legislation adopted by Parliament during this period considered in the context of the Coalition agreement where appropriate. Although party manifestos have long had constitutional significance (for instance, where the House of Lords by convention gives a second reading to legislation included in a manifesto), the formal agreement between the parties sets out a multi-year, post-election agenda for legislation and policy. This provides a more comprehensive account of the intentions of the Government than the annual Speech from the Throne, which is focused on an individual session of Parliament. The more significant instances of secondary legislation and policy documents are considered, as are EU measures (primarily those measures where Member States had some discretion in implementation or where there is a meaningful link with a national-level debate or controversy). I make particular use of material from the last five years of SCRIPTed as many of the Coalition's projects have already been discussed and critiqued in these pages.

Reviewing this material allows for the work of the Coalition to be grouped into four categories. The first category ('rollback') is characterised by the repeal of existing legislative provisions, justified by concerns regarding civil liberties or over-interference on the part of the State. The second category ('rebalancing') is similar, but has its concern the revision of large bodies of law, which remain in place but with the balance between different interests demonstrably amended. The third category ('re-regulation') is controversial as it is made up of legislative initiatives that introduce new provisions (including criminal law) - some of which were not set out in the Coalition agreement, but instead responded to external stimuli and new phenomena. Finally, a fourth ('projects') category brings together what are primarily policy initiatives, with legislative and nonlegislative measures adding up to a cluster of actions around specific themes. I conclude with a review of 'unfinished business' and some final observations on the Coalition's record.

\section{Rollback}

This first category of Coalition activity can be described as 'rollback', on the grounds that the avowed intention of the Government was to repeal or substantially amend existing legislation

\footnotetext{
${ }^{1}$ HM Government, "The Coalition: our programme for government" (2010) available at https:/www.gov.uk/government/uploads/system/uploads/attachment_data/file/78977/coalition_programme_for_govern ment.pdf ['Coalition Agreement'] (accessed 01 May 2015).
} 
and/or practice. Typically, these changes were flagged up in the Coalition agreement, and appeared in one (or both) of the manifestos of the participating parties.

The first piece of relevant legislation was the Identity Documents Act 2010. This repealed legislation on identity cards (Identity Cards Act 2006) as part of the Coalition's commitment to abandon the scheme. ${ }^{2}$ This represented a very clear break with the perceived intrusiveness of the previous Labour government demonstrated symbolically by the responsible Minister (Damien Green) who was pictured assisting with the physical destruction of hard drives on which ID card information was stored. ${ }^{3}$

A broader and more complex package of changes, again highlighted in the Coalition agreement, ${ }^{4}$ was included in the Protection of Freedoms Act 2012. This Act included provisions on DNA retention, ${ }^{5}$ biometrics ${ }^{6}$ oversight of $\mathrm{CCTV},{ }^{7}$ and amendments to the Regulation of Investigatory Powers Act (RIPA) $2000 .{ }^{8}$ On their own, some of these measures might fit more comfortably in the later 'rebalancing' category. However, the deliberate packaging of them in a piece of legislation on 'freedoms', as promised in the 'civil liberties' chapter of the agreement, demonstrates the high water mark of a libertarian strand of thinking in the Government and even supports a case that they be recorded as more than the sum of their parts.

Evidence of the 'rollback' approach is however not only found in major legislative proposals. For example, schedule 21 ('miscellaneous unnecessary regulation') of the Enterprise and Regulatory Reform Act 2013, and related secondary legislation, ${ }^{9}$ removed the duty on television retailers to record and report the details of customers (to support the TV Licence system).

A more contentious example is the repeal of sections 17/18 Digital Economy Act 2010. These provisions, adopted in the very last days of the previous Parliament (before the 2010 election), were a move towards a statutory system for Internet blocking injunctions. That is, the provisions would, if implemented, have allowed for rights holders to apply to the High Court for an injunction against an intermediary (in practice, an Internet access provider) that would require the blocking of access to a specified 'location on the Internet'.

However, in practice an expansive interpretation of section 97A Copyright, Designs and Patents Act 1988 (adopted in 2003 to transpose the 2001 Information Society Directive) in respect of copyright infringement, ${ }^{10}$ and latterly the use of wider powers (in the context of the IP Rights

\footnotetext{
${ }^{2}$ Ibid 11 .

${ }^{3}$ SA Mathieson, "Minister Damian Green shows an ID card hard drive ready to be destroyed" (30 November 2012) available at samathieson.com/sa-mathieson/minister-damian-green-destroys-id-cards-national-identity-register/idregister-4/ (accessed 01 May 2015).

${ }^{4}$ Coalition Agreement, see note 1 above, at 11.

${ }^{5}$ Protection of Freedoms Act 2012, part 1, chapter 1.

${ }^{6} \mathrm{Ibid}$; see also ch 2 (children).

${ }^{7}$ Ibid part 2, ch 1 (see in particular s 29, establishing a new code of practice for surveillance camera systems).

${ }^{8}$ Ibid part 2, ch 2 (inserting new sections on judicial approval for various authorisations under RIPA).

${ }^{9}$ Enterprise and Regulatory Reform Act 2013 (Broadcasting Consequential Amendments) Order 2013, SI 2013/1854.

${ }^{10}$ 20th Century Fox v BT (no 2), [2011] EWHC 1981(Ch) (availability of injunction against ISP on basis of findings of infringement against a website in earlier proceedings, including the ISP's use of existing 'Cleanfeed' system); 20th Century Fox v BT (no 2), [2011] EWHC 2714 (Ch) (form of injunction); Dramatico v British Sky Broadcasting, [2012] EWHC 268 (Ch) (finding of infringement regarding unrepresented website, in proceedings against ISP); EMI v British Sky Broadcasting, [2013] EWHC 379 (Ch) (single decision regarding infringement and injunction).
} 
Enforcement Directive $)^{11}$ beyond copyright, has meant that such injunctions are readily available against ISPs on the application of affected rights holders and with increasingly little fuss. Ofcom was in 2010 critical of the feasibility of the DEA provisions (in response to a request from the new Government), ${ }^{12}$ and the Government committed in 2011 not to implement them ${ }^{13}$ and then in 2012 to their repeal. ${ }^{14}$ The provisions never came into force at all, and were finally repealed in the Deregulation Act 2015, s 56 (ironically, adopted right before the 2015 election).

\section{Rebalancing}

The second category is 'rebalancing'. In this category, we find major, established areas of private law, where the Government has researched and/or successfully proposed changes that, taken as a whole, amend the balance between the different interests affected by the law in a clearly demonstrable fashion.

The first such example is the Defamation Act 2013. The Coalition agreement included a broad commitment to "review libel laws to protect freedom of speech". ${ }^{15}$ Thus, both the intention and the desired objective were linked in this one-line mission statement. The resulting legislation, based on a draft Bill ${ }^{16}$ and pre-legislative scrutiny by a parliamentary committee, ${ }^{17}$ as well as previous reports and a Private Members Bill in the House of Lords, was indeed a reform project with a goal in mind, rather than a comprehensive codification or review.

The new provisions generally favour the interests of potential defendants in libel actions. These provisions deal with single publication, jurisdiction, the threshold for the cause of action, and yet another variation on protection for Internet intermediaries (including a new concept of the 'operator of a website'). These changes attracted some criticism, ${ }^{18}$ but were broadly welcomed and supported by some of those affected, including publishers, journalists, and scientists. ${ }^{19}$ Nonetheless, the law of Northern Ireland remains in essence at the pre-2013 position, and, alongside the already different Scottish provisions, the impact of the reforms across the UK as a whole is limited.

\footnotetext{
${ }^{11}$ Directive 2004/48/EC of the European Parliament and of the Council of 29 April 2004 on the enforcement of intellectual property rights, article 11 . No amendment was made to UK law to transpose this provision, on the grounds that injunctions were already provided for in the Senior Courts Act 1981, s 37. For a successful application for an injunction under s 37 and the Directive, in respect of trade marks, see Cartier International v British Sky Broadcasting, [2014] EWHC 3354 (Ch).

${ }^{12}$ Ofcom, "'Site blocking' to reduce online copyright infringement: a review of section 17 \& 18 of the Digital Economy Act” (27 May 2010) available at stakeholders.ofcom.org.uk/binaries/internet/site-blocking.pdf (accessed 01 May 2015).

${ }^{13}$ https:/www.gov.uk/government/uploads/system/uploads/attachment_data/file/78090/Next-steps-for-implementationof-the-Digital-Economy-Act.pdf (accessed 01 May 2015).

${ }^{14}$ Department for Culture, Media \& Sport, "Measures to tackle Internet piracy moved forward today (26 June 2012) available at https:/www.gov.uk/government/news/next-steps-to-tackle-internet-piracy (accessed 01 May 2015).

${ }^{15}$ Coalition Agreement, see note 1 above, at 11.

${ }^{16} \mathrm{Cm} 8020$.

${ }^{17}$ Joint Committee on the Draft Defamation Bill (2010-2012) HL 203, HC 930; see also Government response, Cm 8295.

${ }^{18}$ A Mullis \& A Scott, "The Swing of the Pendulum: Reputation, Expression and the Recentering of English Libel Law" (2012) 63 Northern Ireland Legal Quarterly 27; D Howarth, "Libel: its purpose and reform" (2011) 74 Modern Law Review 845 (criticising the reform project on the grounds that it fails to identify the purposes of defamation law and the significance of reputation under article 8 ECHR).

${ }^{19}$ See for example the statements from Sense About Science and the Libel Reform Campaign http://www.senseaboutscience.org/news.php/367/defamation-act-2013-has-come-into-force; http://www.libelreform.org/latest-news/libel-reform-england-and-wales (accessed 01 May 2015).
} 
In copyright law, the Government set up the Hargreaves Review, ${ }^{20}$ which built on the work of the Gowers Review ${ }^{21}$ under a previous administration. This was not its only IP project; the Intellectual Property Act 2014 amended the law of designs and patents, and Part 6 of the Enterprise and Regulatory Reform Act 2013 brought about changes to copyright law in respect of performances. However, the long gestation of the changes (eventually adopted by statutory instrument in 2014) ${ }^{22}$ points to the significance and controversy of the project. The 'Hargreaves amendments' included a new statutory exception for works of parody, caricature and pastiche; various protections for libraries, archives, cultural institutions and educational institutions; and a scheme to allow private copying without remuneration (which is under challenge on the grounds of compatibility with EU law $\left.{ }^{23}\right)$. Broadly, these changes restrict the exercise of exclusive rights under copyright law, although many were supported by technology industries. The freedom of action of the Government was constrained by EU law (whatever the result of the current judicial review), so the new provisions are intended to fit within what is permissible under the Information Society Directive. Nonetheless, the whole package - and the extensive economic evidence assembled during and after Hargreaves - is a lasting contribution to the field of copyright law.

Before leaving this category, we could also consider an area of public law, the proposed Privacy and Civil Liberties Board, which is provided for (subject to future secondary legislation) in the Counter-terrorism and Security Act 2015 s 46. This Board, which was proposed during discussion of data retention legislation (see part 4, below), would allow the Home Secretary to appoint a board to support independent reviewers of terrorism powers. Its mandate is to be set out by statutory instrument. The inclusion of these provisions in counter-terrorism legislation is semantically uncomfortable, but does assist the scholar in categorising the initiative as an attempt to address a perception that one set of interests (security) dominates over another (privacy) and requires rebalancing. However, because secondary legislation was not adopted before the election, some caution is necessary in attributing much force to it, not least with the incoming Government being reported to be considering new legislation on communications data now that the objections of the Liberal Democrat party can only be expressed from the Opposition benches rather than at Cabinet. $^{24}$

\footnotetext{
${ }^{20}$ Ian Hargreaves, "Digital opportunity: review of intellectual property and growth" (May 2011) available at

https://www.gov.uk/government/publications/digital-opportunity-review-of-intellectual-property-and-growth (accessed 01 May 2015).

${ }^{21}$ HM Treasury, "Gowers Review of Intellectual Property” (December 2006) available at https://www.gov.uk/government/uploads/system/uploads/attachment_data/file/228849/0118404830.pdf (accessed 01 May 2015).

${ }^{22}$ E.g. Copyright and Rights in Performances (Personal Copies for Private Use) Regulations 2014, SI 2014/2361; Copyright and Rights in Performances (Quotation and Parody) Regulations 2014, SI 2014/2356; Copyright and Rights in Performances (Research, Education, Libraries and Archives) Regulations 2014, SI 2014/1372.

23 "MU, BASCA and UK Music Launch Judicial Review" (26 November 2014) available at www.musiciansunion.org.uk/news/2014/11/26/mu-basca-and-uk-music-launch-judicial-review/ (accessed 01 May 2015) (application for judicial review); "High Court grants permission for music industry to pursue a judicial review" (16 January 2015) available at http://www.musiciansunion.org.uk/news/2015/01/16/high-court-grants-permission-formusic-industry-to-pursue-a-judicial-review/ (accessed 01 May 2015) (permission granted); "Private Copying Judicial Review Heard At High Court" (30 April 2015) available at http://www.ukmusic.org/news/private-copying-judicialreview-heard-at-high-court (accessed 01 May 2015) (hearing).

${ }^{24}$ A Withnall, "Snoopers' Charter: Theresa May's plan to push ahead with Communications Data Bill sparks online campaign for internet freedom" (The Independent 10 May 2015) available at http:/www.independent.co.uk/news/uk/politics/generalelection/snoopers-charter-theresa-mays-plan-to-push-aheadwith-communications-data-bill-sparks-online-campaign-for-internet-freedom-10239945.html (accessed 01 May 2015).
} 


\section{Re-regulation}

This third category is a more controversial one. In the later days of the Coalition, a number of measures providing for new forms of control in respect of how individuals use the Internet were put to Parliament by the Government. In many cases, these measures reverse or significantly depart from the law as it stood when the Coalition took power in 2010.

One cannot avoid starting with the controversial, speedily-adopted Data Retention and Investigatory Powers Act 2014. Commonly known as the DRIP Act, it was ostensibly introduced to fill the lacuna following the Court of Justice of the European Union (CJEU)'s finding that the Data Retention Directive was not valid due to infringement of fundamental rights. ${ }^{25}$ In the Coalition agreement, the parties had committed that they would "end the storage of internet and email records without good reason." 26

The Act readopted in primary legislation much of the secondary legislation initially introduced as transposition of the Directive (under the previous Government), and authorised new secondary legislation. ${ }^{27}$ What is provided for, in $\mathrm{s} 1$, is the mandatory retention of communications data for up to 12 months by designated Internet service providers (access to the retained data is governed separately by RIPA). In addition, further changes were made to the law on surveillance, namely broader updates to RIPA on extra-territorial effects and the scope of 'telecommunications service'. The legislation was given limited consideration by Parliament in summer 2014 - all stages in one day in the House of Commons, with consideration by the House of Lords (without amendments being made) and Royal Assent following within two further days.

The DRIP Act has already been extended by way of s 21 Counter-Terrorism and Security Act 2015, which provide in effect for the further retention of data that will allow the association of devices with IP addresses. ${ }^{28}$ The Act, including the 2015 amendment, was subject to a 'sunset clause' of the end of 2016. However, shortly after the 2015 election, the High Court found s 1 DRIP Act incompatible with EU law, including the Charter of Fundamental Rights, and disapplied it. ${ }^{29}$ As such, the incoming Government must return to the matter sooner rather than later; the High Court's finding was suspended until March 2016 to allow for an appropriate scheme to be put in place.

An even clearer example of the Government's changing attitude to the Internet is found in the Audiovisual Media Services Regulations $2014 .^{30}$ These provisions amend the scheme for regulating

\footnotetext{
${ }^{25}$ Case C-293/12 Digital Rights Ireland and Case C-594/12 Kärntner Landesregierung; discussed in J Rauhofer and D Mac Síthigh, "The Data Retention Directive Never Existed" (2014) 11 SCRIPTed 118 http://script-ed.org/?p=1480 (accessed 01 May 2015).

${ }^{26}$ Coalition Agreement, see note 1 above, at 11.

${ }^{27}$ Data Retention Regulations 2014, SI 2014/2042

${ }^{28}$ See criticism in Liberty, "Second reading briefing on the Counter-Terrorism and Security Bill in the House of Commons" (December 2014) available at https://www.liberty-humanrights.org.uk/sites/default/files/Liberty's\%20Second\%20Reading $\% 20$ Briefing $\% 20$ on $\% 20$ the $\% 20$ CounterTerrorism\%20\%26\%20Security\%20Bill\%20in\%20the\%20House\%20of\%20Commons.pdf [40-43] (accessed 01 May 2015).

${ }^{29}$ Davis $v$ Secretary of State for the Home Department [2015] EWHC 2092 (Admin). See also J Rauhofer, W Abel and I Brown, "A First Look at the Constitutional and Legal Implications of the Data Retention and Investigatory Powers Act 2014” (2014) 11 SCRIPTed 320 available at http://script-ed.org/?p=1673 (accessed 01 May 2015).

${ }^{30}$ SI $2014 / 2916$
} 
on-demand services, which were put in place in 2009/10 following the 2007 AVMS Directive. ${ }^{31}$ While the previous Government had been a vocal critic of the perceived over-regulation of ondemand services, these new provisions (essentially applying BBFC standards on explicit content to on-demand services) go well beyond those in other EU states. The issue of restricting access to, and in some cases prohibiting outright online video services, was a matter of some concern to the Department for Culture, Media \& Sport. Activities during the lifetime of the Coalition included the DCMS asking Ofcom to study the matter, ${ }^{32}$ regular consideration (and the exercise of existing powers) by the designed co-regulatory body ATVOD and by Ofcom, ${ }^{33}$ and ongoing discussion of how far the UK could go without contravening the Directive. ${ }^{34}$

Similarly, the Gambling (Licensing and Advertising) Act 2014 was an attempt to put in place, within the bounds of EU law, further restrictions on online gambling. The Gambling Act 2005 facilitated the advertising of online services from selected jurisdictions (EU and those on a 'whitelist' of countries with sufficiently robust regulatory mechanisms), and did not require providers located outside the jurisdiction to be regulated by the Gambling Commission. The 2014 Act reverses both principles. ${ }^{35}$ Now, where a service is used or likely to be used by users in Great Britain $^{36}$ (if the operator knows or should know that), the Gambling Commission has regulatory jurisdiction. Only services regulated by the Commission can lawfully advertise in the UK. ${ }^{37}$ This legislation survived a legal challenge from Gibraltar-based operators, ${ }^{38}$ and clearly responded to a degree of tolerance demonstrated by the CJEU in respect of similar legislation emanating from other member states. ${ }^{39}$

Most recently, various criminal offences of some significance have been created or extended. The Criminal Justice and Courts Act 2015 extends the penalty for breach of the Malicious Communications Act 1988 to a maximum 2 years imprisonment on indictment (s 32). It also extends the scope of the 'extreme pornography' provisions enacted by the previous Parliament, through s 37's amendment of the Criminal Justice and Immigration Act 2008. This was introduced to address a 'loophole', ${ }^{40}$ although the evidence was more nuanced than this label suggests. ${ }^{41}$

\footnotetext{
${ }^{31}$ Directive 2010/13/EU on the coordination of certain provisions laid down by law, regulation or administrative action in Member States concerning the provision of audiovisual media services [2010] OJ L95 (consolidating Directives 2007/65/EC, 89/552/EEC and 97/36/EC). In the UK, see Audiovisual Media Services Regulations 2009, SI $2009 / 2979$.

32 Ofcom, "Sexually explicit material and video on demand services" (4 August 2011).

${ }^{33}$ J Petley, “The regulation of pornography on video-on-demand in the United Kingdom” (2014) 1 Porn Studies 276.

${ }^{34}$ Department for Culture, Media and Sport, “Connectivity, Content and Consumers: Britain's digital platform for growth" (July 2013) available at https://www.gov.uk/government/uploads/system/uploads/attachment_data/file/225783/Connectivity_Content_and_Cons umers_2013.pdf 35 (accessed 01 May 2015).

${ }^{35}$ D Mac Síthigh, "When the Dealin's Done: Recent Developments in Online Gambling Law and Policy” (2014) 11 SCRIPTed 171 available at http://script-ed.org/?p=1541 (accessed 01 May 2015).

${ }^{36}$ As with much of the Gambling Act 2005, this provision is directed at 'Britain' (i.e. England, Scotland and Wales) rather than the UK (i.e. including Northern Ireland).

${ }^{37}$ The advertising rules apply (through a separate provision) in Northern Ireland.

${ }^{38}$ Gibraltar Betting \& Gaming Association v Secretary of State for Culture, Media \& Sport, [2014] EWHC 3236 (Admin).

${ }^{39}$ E.g. Sjöberg, [2011] 1 CMLR 11; Hit Hoteli \& Hit Larix, [2012] 3 CMLR 39.

${ }^{40}$ Ministry of Justice, "Impact Assessment: extension to the extreme pornography possession offence" (5 February 2014) available at http://www.parliament.uk/documents/impact-assessments/IA14-03E.pdf (accessed 01 May 2015).

${ }^{41}$ C McGlynn and E Rackley, "Criminalising extreme pornography: a lost opportunity" [2009] Criminal Law Review 245; cf F Attwood and C Smith, "Extreme Concern: Regulating 'Dangerous Pictures' in the United Kingdom” (2010)
} 
Famously, the Act also contains an entirely new offence in s 33, of 'disclosing private sexual photographs and films with intent to cause distress' - often, but not entirely accurately, referred to as the 'revenge pornography' clause. Of particular note is the focus upon distress as an element of the offence. Although without doubt a difficult and sensitive issue, these provisions were introduced without a committee stage in the House of Commons, and with limited research or consultation. Unfortunately, this provision encapsulates a common problem in Internet law, of creating a new offence without the methodical consideration of existing offences or an attempt to put in place a meaningful set of workable, understandable provisions.

Less controversially, the Serious Crime Act 2015 also contains new provisions on possession of any item that contains advice or guidance about abusing children sexually (s 69) and sexual communication with a child (s 67).

Taking all of these criminal provisions together, we see the gradual growth of criminal sanctions in areas that surely demands more thorough consideration. At least in respect of the MCA and 'revenge pornography' offences, the House of Lords Communication Committee's 2014 report on social media and criminal offences would be a sensible starting point. ${ }^{42}$ In this context, the amendments to the Computer Misuse Act 1990 contained in part 2 of the Serious Crime Act 2015 (some required in order to transpose a Directive on attacks against information systems ${ }^{43}$ and others introduced as part of the Government's cybersecurity strategy ${ }^{44}$ ) can be noted as a further example of piecemeal revision of IT law.

\section{Projects}

A final category is major projects. ${ }^{45}$ These include open data, consumer law, creative industries tax relief, local media, and the Leveson Inquiry.

Open data is an area where the Coalition has been very active, at least in terms of policy statements and reports. Its manifesto included commitments to openness in principle and further points of detail. Since then, we have seen a White Paper in $2012,{ }^{46}$ a review on public sector information in

37 Journal of Law and Society 171; see also written evidence submitted by Feona Attwood, Martin Barker and Clarissa Smith, PBC (Bill 169) 2013-14, CJC 06.

${ }^{42}$ House of Lords Communications Committee, "Social media and criminal offences" (2014-15) HL Paper 37 available at www.publications.parliament.uk/pa/ld201415/ldselect/ldcomuni/37/3702.htm (accessed 01 May 2015).

${ }^{43}$ Directive 2013/40/EU of the European Parliament and of the Council of 12 August 2013 on attacks against information systems.

${ }^{44}$ A new offence (s 41) of impairing a computer such as to cause serious damage of a material kind (e.g. damage to national security, the economy or environment), with maximum penalties ranging between 14 years and life imprisonment. See also D Read, "Should the English Legal System Adopt the US Law of Cyber-trespass?" (2011) 8 SCRIPTed 46 available at http://www2.law.ed.ac.uk/ahrc/script-ed/vol8-1/read.asp (accessed 01 May 2015).

${ }^{45}$ There were other projects of less political salience, such as the work that the Law Commission did on jurors, in the context of contempt of court. Its project was wide-ranging, and led to timely legislation; new provisions were included in the Criminal Justice and Courts Act 2015, dealing with the carrying out of research by jurors and the use of electronic devices. See Law Commission, "Contempt of court: juror misconduct and Internet publications" (2013) Law Com No 340 .

${ }^{46}$ Cabinet Office, “Open Data White Paper: unleashing the potential” (June 2012) Cm 8353 available at http://data.gov.uk/sites/default/files/Open_data_White_Paper.pdf (accessed 01 May 2015). 
$2013,{ }^{47}$ and a further review on anonymisation. Open Data Strategies have been adopted at department level, prompted by communications from the Prime Minister. ${ }^{48}$ Data.gov.uk is a repository of data and highlights innovative uses, including apps, of public sector data. An Open Data Institute, with a focus on private-sector activity, has been created. Finally, the National Audit Office carried out a review in 2012, finding that some progress has been made, but cautioning that more careful evaluation is necessary so as to ensure value for money and consistent application of new policies. ${ }^{49}$

Legislatively the changes were at a smaller scale. The Coalition agreement set out two key goals that could have required legislation: the creation of "a new 'right to data' so that government-held datasets can be requested and used by the public and then published on a regular basis", and ensuring "that all data published by public bodies is published in an open and standardised format so that it can be used easily and with minimal cost by third parties". ${ }^{50}$ The Protection of Freedoms Act 2012 included amendments to the Freedom of Information Act 2010 in support of the release of usable datasets. In particular, public authorities are now required, where reasonably practicable, to release datasets in a reusable electronic format and (where applicable) under a suitable licence when a relevant FOI request is received. However, the 'right to data' as of 2015 may more accurately be understood as a combination of the amended FOI Act and the series of Government policies adopted and initiatives taken (both without legislation) during the period of office of the Coalition. This reflects a statement in the 2012 White Paper that "we don't want to use legislation too readily that would sit at odds with our core principle to reduce bureaucracy". 51

More contentiously, the Health \& Social Care Act 2012 put in place various regimes in relation to health data. In particular, the 'pausing' of the care.data project in 2014 highlighted both unaddressed critiques of the 2012 Act and a high level of public concern about the relationship between health data and individual privacy. ${ }^{52}$

The consumer law reform project deserves further attention. The Coalition agreement did not deal with the matter in detail, beyond a general commitment to "introduc(ing) stronger consumer protections, including measures to end unfair bank and financial transaction charges." $" 53$ The issue was brought into focus through the transposition of the Consumer Rights Directive, which had at one time been a planned overhaul of the EU consumer law acquis, but turned out to be something a lot less extensive. Subsequently, the Consumer Rights Act 2015 was adopted by Parliament, after

\footnotetext{
${ }^{47}$ Stephan Shakespeare, “An independent review of public sector information” (May 2013) available at https://www.gov.uk/government/uploads/system/uploads/attachment data/file/198752/13-744-shakespeare-review-ofpublic-sector-information.pdf (accessed 01 May 2015).

${ }^{48}$ Letter (31 May 2010) available at

http://webarchive.nationalarchives.gov.uk/20130109092234/http://number10.gov.uk/news/letter-to-governmentdepartments-on-opening-up-data/ (accessed 01 May 2015); Letter (7 July 2011) available at https://www.gov.uk/government/news/letter-to-cabinet-ministers-on-transparency-and-open-data (accessed 01 May 2015).

${ }^{49}$ National Audit Office, "Implementing transparency” (2010-12) HC 1833

${ }^{50}$ Coalition Agreement, see note 1 above, at 21.

${ }^{51}$ Open Data White Paper, see note 46 above, at 13.

${ }^{52}$ M Taylor, "Information Governance as a Force for Good? Lessons to be Learnt from Care.data", (2014) 11 SCRIPTed 1 available at http://script-ed.org/?p=1377 (accessed 01 May 2015). See also M Oswald, "Share and share alike? An examination of trust, anonymisation and data sharing with particular reference to an exploratory research project investigating attitudes to sharing personal data with the public sector" (2014) 11 SCRIPTed 245 available at http://script-ed.org/?p=1667 (accessed 01 May 2015).

${ }^{53}$ Coalition Agreement, see note 1 above, at 13.
} 
lengthy consideration. The Act, in line with the recommendations of a number of reports requested by the previous Government, ${ }^{54}$ addressed a long-standing potential gap in consumer law - which has a firm distinction between the sale of goods and the supply of services - without properly addressing the position of 'digital content'. The new Act creates a three-tier structure with much, but not all, of the existing or reframed requirements for goods being applied to the new digital content category.

Creative industries tax relief was the subject of a notable shift in direction. ${ }^{55}$ The incoming Government initially abandoned video games tax relief on the grounds that it was 'poorly targeted'. ${ }^{56}$ However, it subsequently introduced a new relief for games, high-end television, and animation, implemented as amendments to the Corporation Tax Act 2009 in the Finance Act 2013. The games scheme was delayed pending consideration by the European Commission, but was ultimately approved ${ }^{57}$ and is now in force. Indeed, a follow-up set of changes introduces relief for theatre as well (Finance Act 2014). The adopting of the games scheme highlights how the Coalition has been able to promote its intervention as an industrial measure in the UK, while reassuring the European Commission that its objectives were truly cultural. ${ }^{58}$

Similarly, identifying the objectives of the 'local media' project is not an easy task. The question of local television was an early theme of the Department for Culture, Media and Sport, with the initial Secretary of State frequently wondering why local TV was in a better state in Birmingham, Alabama than in Birmingham, England. ${ }^{59}$ Beyond the soundbite, a number of specific changes were made. The Communications Act 2003 was amended twice: first in 2011 to liberalise some crossownership requirements, and then again in 2012 to put in place a new form of licence for local TV stations. ${ }^{60}$ Interestingly, the new form of licensing was an unusually qualitative process, much closer in criteria to the old 'beauty contest' mode adopted for ITV regional licences, and with legislative requirements including a definition of localness ${ }^{61}$ and prohibitions on pornography and chat services $^{62}$. Some of these services are already up and running, but requests to depart from the

\footnotetext{
${ }^{54}$ Robert Bradgate, "Consumer rights in digital products" (September 2010) available at https://www.gov.uk/government/uploads/system/uploads/attachment_data/file/31837/10-1125-consumer-rights-indigital-products.pdf (accessed 01 May 2015). On the need to clarify consumer law more generally, see e.g. Centre for Competition Policy, "Benchmarking the performance of the UK framework supporting consumer empowerment through comparison against relevant international comparator countries" (2008) available at http://competitionpolicy.ac.uk/documents/107435/107584/file50027.pdf (accessed 01 May 2015); G Howells \& C Twigg-Flesner, "Consolidation and Simplification of UK Consumer Law" (October 2010) available at https:/www.gov.uk/government/uploads/system/uploads/attachment data/file/31838/10-1255-consolidationsimplification-uk-consumer-law.pdf (accessed 01 May 2015).

${ }^{55}$ See discussion in D Mac Síthigh, "Multiplayer games: tax, copyright, consumers and the video game industries" (2014) 5 European Journal of Law and Technology available at ejlt.org/article/view/324 (accessed 01 May 2015).

${ }^{56}$ Hansard HC vol 512 col 175 (22 June 2010).

${ }^{57}$ A.36139 "Video games tax reliefe [2013] OJ C 152 (30 May 2013).

${ }^{58}$ Mac Síthigh, see note 55 above.

${ }^{59}$ E.g. J Hunt, "Media keynote speech" (9 June 2010) available at https://www.gov.uk/government/speeches/mediakeynote-speech (accessed 01 May 2015).

${ }^{60}$ Local Digital Television Programme Services Order 2012, SI 2012/292.

${ }^{61}$ Ibid, s 3.

${ }^{62}$ Ibid, sch 1.
} 
commitments made during the application round are already being considered and in some cases granted. $^{63}$

A final project, or partial project, is the Leveson Inquiry. This was not envisaged in the Coalition agreement, as the question of phone-hacking did not come to a head until summer 2011. Leveson's recommendations were acknowledged in part through the inclusion of provisions in the Crime and Courts Act 2013 (linking participation in a recognised self-regulatory scheme to the question of exemplary damages for certain media-related causes of action e.g. defamation), and a broadlyworded clause in s 96 Enterprise and Regulatory Reform Act 2013 on the relationship between Parliament and Royal Charters for specific industries. This latter clause was part of the Government's attempt to provide for some measure of press regulation without formal statutory control. A Royal Charter has indeed now been approved by the Privy Council, establishing a Recognition Panel for the purpose of recognising independent self-regulatory bodies. ${ }^{64}$ However, no recognition has taken place to date.

Other recommendations in the Leveson report, especially on data protection and media pluralism, remain unimplemented at a legislative level.

\section{Unfinished business}

The present review of the Coalition's record also allows for the identification of unfinished or emerging issues. These are three broad categories: (a) data and information, (b) media and telecommunications regulation, and (c) e-commerce.

Eventually, the EU is likely to adopt a General Data Protection Regulation, ${ }^{65}$ which may lead to a debate at national level for other or related issues. ${ }^{66}$ There are indeed a range of questions arising out of the ongoing interest in data and the law. The Law Commission's project on data sharing has so far provided a scoping report, ${ }^{67}$ which sets out very explicitly the complexity of the legislative changes that could be necessary to support the goal of data sharing. The long-term position of data retention will need to be resolved after DRIP expires (see part 4, above), and the Justice Committee's post-legislative scrutiny of the FOI $\mathrm{Act}^{68}$ (proposing attention to review procedures, which bodies are covered, and other matters) could also be a useful starting point for a future Government.

Many would have predicted, given DCMS activity and proposals, that this Government would have proposed and secured support for a new Communications Act, in the fields of broadcasting and

\footnotetext{
${ }^{63}$ Ofcom, "ESTV change request" (8 October 2014) available at http://licensing.ofcom.org.uk/binaries/tv/localtv/london/Final Decision ESTV.pdf (accessed 01 May 2015);

64 "Royal Charter on self-regulation of the press" (30 October 2013) available at https://www.gov.uk/government/uploads/system/uploads/attachment data/file/254116/Final Royal Charter 25 Octobe r 2013 clean Final .pdf (accessed 01 May 2015).

${ }^{65}$ Reviewed in G Hornung, “A General Data Protection Regulation For Europe? Light And Shade In The Commission's Draft Of 25 January 2012” (2012) 9 SCRIPTed 64 available at http://script-ed.org/?p=406 (accessed 01 May 2015).

${ }^{66}$ See contributions to S Gutwirth, R Leenes, and P de Hert (eds), Reforming European Data Protection Law (Dordrecht: Springer, 2015).

${ }^{67}$ Law Commission, "Data Sharing between Public Bodies: A Scoping Report" (2014) Law Com No 351 available at lawcommission.justice.gov.uk/areas/data-sharing.htm (accessed 01 May 2015).

${ }^{68}$ House of Commons Justice Committee, "Post-legislative scrutiny of the Freedom of Information Act 2000" (201213) HC 96.
} 
telecommunications. The 2003 Act has been amended including in the ways noted above (mostly through secondary legislation), and other provisions are politically contentious (e.g. the future of public service broadcasting). Initially, it was expected that a Green Paper and White Paper would be published. In 2011, the Secretary of State highlighted that it had been seven years since the previous Act ("a long time in today's fast-paced environment", and emphasised a need for "the most modern, innovation and investment-friendly legal structure". ${ }^{99}$ However, the Green Paper was replaced by a series of 'seminar papers' in what was branded as the Communications Review, still with a view to a Bill in the final session of Parliament. ${ }^{70}$ Then, in a 2013 statement, the Government explained that "rather than making sweeping changes to legislation, instead [it was] proposing to make incremental changes - updating the framework of [the Communications Act 2003] as necessary". ${ }^{71}$ Will the next Parliament be asked to consider a Communications Bill, ten years since the Act? In any event, the BBC's Royal Charter will be due for renewal in 2016, and the future of the licence fee was immediately taken up by the incoming Government.

The sub-question of broadband infrastructure was considered primarily from a policy point of view during the life of the Coalition, including significant financial commitments. ${ }^{72}$ However, part of the implementation of the desire to see 'world-class connectivity' involves the consideration of rights to build new networks. The Law Commission's 2013 report on the Electronic Communications Code ${ }^{73}$ (provisions governing access to and use of land) was to be implemented through an Infrastructure Bill. However, the provisions were withdrawn from what became the Infrastructure Act 2015, and a separate consultation took place in spring 2015, on the basis of a Draft Bill specifically dealing with the Code. ${ }^{74}$

Finally, although the law on e-commerce remains relatively stable this may not be the case for long. The European Commission has restated its commitment to new measures in order to support the 'digital single market'. At home as well as in the EU a specific issue that has emerged within the Coalition's period of office is the regulation of the sharing economy. A review took place in 2014, with various changes to the law being recommended. ${ }^{75}$ The report was broad, and although promoted as 'independent' was written by a founder of a home-swapping company. Already, the Deregulation Act 2015 makes a specific amendment supporting private short-term letting of property in London (amending planning law from the 1970s), addressing one particular threat to the business model of Airbnb and similar enterprises. However, the controversy associated with this field, and the existence of a report, could well keep this matter on the agenda.

\footnotetext{
${ }^{69}$ J Hunt, "Speech to the Oxford Media Convention" (19 January 2011) available at https://www.gov.uk/government/speeches/oxford-media-convention (accessed 01 May 2015).

${ }^{70}$ http://webarchive.nationalarchives.gov.uk/20120913095731/http://dcmscommsreview.readandcomment.com/aboutthe-communications-review/ (accessed 01 May 2015).

${ }^{71}$ Connectivity, Content and Consumers, see note 34 above, at 14 . One of the areas identified for earlier action was 'nuisance calls' (ibid 37-8), which was implemented through lowering the threshold for the imposition of financial penalties, in the Privacy and Electronic Communications (EC Directive) (Amendment) Regulations 2015, SI $2015 / 355$. Another point was the changes to the regulation of video-on-demand, discussed in part 5, above.

${ }^{72}$ Connectivity, Content and Consumers, see note 34 above, at 17-21.

${ }^{73}$ Law Commission, "The Electronic Communications Code" (2013) Law Com No 336 available at lawcommission.justice.gov.uk/areas/electronic-communications-code.htm (accessed 01 May 2015).

${ }^{74}$ Department for Culture, Media \& Sport, "Consultation on Reforming the Electronic Communications Code" (26 February 2015) available at https:/www.gov.uk/government/consultations/consultation-on-reforming-the-electroniccommunications-code (accessed 01 May 2015).

${ }^{75}$ https://www.gov.uk/government/publications/unlocking-the-sharing-economy-independent-review (accessed 01 May 2015).
} 


\section{Conclusion}

The Coalition has acted in a way that has affected a range of technological and creative industries, attracting limited criticism from these quarters. The institutional press was very pleased with the Defamation Act, and the (limited) approach to the Leveson report has offered some reassurances to those concerned with avoiding statutory regulation of the press. New media and IT industries were well served by changes to defamation and copyright law, although the Coalition's attention to data retention did not sit easily alongside these projects. Some in the creative industries (e.g. the established music industry, as well as some photographers) were upset at the copyright changes, but many will have been reassured by the programme of tax credits that their industries are favoured.

Taking a wider perspective, a sceptic might conclude that there was no major legislative project in this field during the lifetime of the Coalition. Open data as a project could be considered the most plausible candidate, although the lack of legislative underpinning is surprising for something argued to be so fundamental to a change in the way of governing. With 130 or so Acts adopted since the 2010 election, only a handful relate to information and technology, and often it was only a clause or two that were relevant. The changes to defamation and copyright law were not complete reassessments or codifications, but the consumer law project (albeit dealing with wider issues than IT law) was a genuinely wide-ranging project.

However, the most striking finding of this study is how the initial urgency of Coalition libertarianism (and related paens to freedom of expression) gave way to a late enthusiasm for Internet (re)regulation. This is not unusual for governments, and the knee-jerk response to perceived disorder or threat is not specific to the Internet, but it is remarkable how the measures in this field adopted over the last 12-18 months have been characterised by the extension of State power in a whole range of areas. The unanticipated slew of new criminal offences, and the undoing of inherited regulatory assumptions on video-on-demand and gambling, highlight a real concern on the part of Government members with the reality of the 'free' Internet. The peace that the Coalition made with aspects of data protection was surprising, although it faced a good deal of internal criticism when the DRIP Act was rushed through Parliament. A reader of the 2015 election manifestos might therefore usefully try to anticipate where the gaps and tensions are, given the arguable 'realignment' of Coalition policy in respect of IT law during its lifetime. 